\title{
Inhibiting Factors of Land Suitability for Piper nigrum L. In a Hilly Area of Tirtomoyo District, Central Java
}

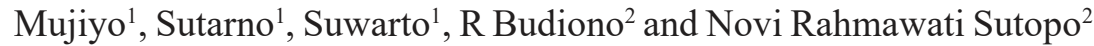 \\ ${ }^{1}$ Department of Soil Science, Faculty of Agriculture, Universitas Sebelas Maret, \\ Ir. Sutami Street No.36A, Jebres, Surakarta 57126, Indonesia ; ${ }^{2}$ Graduate School of Soil Science, \\ Faculty of Agricultural, Universitas Sebelas Maret, Ir. Sutami Street No.36A, Jebres, \\ Surakarta 57126, Indonesia, e-mail: novisutopo@student.uns.ac.id
}

Received September 7, 2019; Revised December 1, 2019; Accepted December19, 2019

\begin{abstract}
Pepper (Piper nigrum L.) has a high selling value. The price of pepper in the domestic or international market that is always high can be a great opportunity to increase farmers' income. Tirtomoyo District is dominated by hilly areas with common soil types of Litosol and Latosol. As one of the efforts to develop the regional economic rate, especially in hilly areas, pepper cultivation can be a solution offered by the agricultural sector. The study was conducted using an explorative descriptive survey method consisting of field observation and laboratory analysis. The analytical unit used was Land Map Unit (LMU) obtained from soil map. The sampling sites were selected using purposive sampling method according to the research objectives and representing the study area. The results show that the actual land suitability for pepper in Tirtomoyo District is marginally suitable (S3) for all LMU. The main limiting factors are water availability and nutrient availability, thus the Tirtomoyo district still have potency for pepper cultivation by applying some improvement measures such as fertilization, irrigation, organic material addition, and cover crop planting.
\end{abstract}

Keywords: Inhibiting factor, land suitability, pepper, Piper nigrum

\begin{abstract}
ABSTRAK
Lada (Piper nigrum L.) merupakan komoditas yang memiliki nilai jual yang tinggi. Harga lada di pasar domestik ataupun internasional yang selalu berada pada level yang tinggi dapat dijadikan peluang besar untuk meningkatkan pendapatan petani. Kecamatan Tirtomoyo di Kabupaten Wonogiri memiliki lahan yang banyak didominasi oleh area perbukitan dengan jenis tanah yang umum dijumpai adalah tanah Litosol dan Latosol. Sebagai salah satu upaya untuk mengembangkan laju perekonomian daerah terutama pada wilayah yang didominasi oleh perbukitan, lada dapat menjadi solusi yang ditawarkan dari sektor pertanian. Penelitian dilakukan dengan metode survei secara explorative descriptive melalui survei lapang yang didukung oleh analisis di laboratorium. Satuan analisis menggunakan Satuan Peta Tanah (SPT) yang didapat dari peta jenis tanah. Titik pengamatan (sampling sites) dipilih secara purposive sampling, sesuai dengan tujuan penelitian serta mewakili lokasi penelitian. Hasil penelitian menunjukkan bahwa kesesuaian lahan aktual untuk tanaman lada pada Kecamatan Tirtomoyo adalah sesuai marjinal (S3) pada keempat SPT (Satuan Peta Tanah) yang ada. Faktor pembatas utama adalah ketersediaan air dan hara, dengan demikian area Tirtomoyo masih berpotensi untuk dilakukan budidaya lada dengan menambahkan beberapa upaya perbaikan seperti pemupukan, irigasi, pemberian bahan organik, dan penanaman tanaman penutup tanah.
\end{abstract}

Kata Kunci: Faktor pembatas, kesesuaian lahan, lada, Piper nigrum

\section{INTRODUCTION}

Pepper (Piper nigrum L.) is one of the most important spicy ingredients of various cuisines in the world, especially in western cuisines, in which $70 \%$

J Trop Soils, Vol. 25, No. 1, 2020: 29-37

ISSN 0852-257X ; E-ISSN 2086-6682 of the cuisines use pepper as one of the ingredients, and about $60 \%$ of eastern cuisines also use pepper (Ravindran 2012). Pepper earns the nickname as "The King of Spices" in the culinary world. Indonesia is the world's second largest pepper producer after Vietnam according to International Pepper Community (IPC 2005). 
Pepper plants do not require extensive land for their cultivation compared to other crops. According to Manohara and Wahyuno (2013), pepper is preferably planted creeping on a living tree such as Gamal (Gliricidia sepium), Dadap (E. variegate), Kapuk (Ceiba pentandra), and Jati/teak (Tectona grandis). Tirtomoyo District in Central Java consisting of 3295 ha of moorland (BPS Wonogiri 2015) dominated by teak and Sengon (Albizia chinensis) plants has the potency for pepper cultivation. This potency is expected to be one of the alternatives that can improve the economy and welfare of the community in Tirtomoyo District.

Providing suitable land is an important aspect of agricultural commodity cultivation (Mujiyo et al. 2017). Evaluation on land suitability is necessary in order to analyze the potency of land and to determine the direction of the development of pepper cultivation, as well as to identify the limiting factors and land suitability for pepper cultivation. In addition, the outcome of land suitability evaluation is necessary to determine land management for optimizing land productivity. Every cultivated agricultural commodity requires a suitable land in order to grow well and provide optimal yields. Land suitability evaluation process is closely related to the evaluation of land quality and its characteristics. Ritung et al. (2011) indicated that land evaluation, which is conducted by interpreting the soil and environmental data, is generally carried out after land survey and land resource mapping. In line with land mapping, land evaluation can also be differentiated based on the availability of data generated on the mapping scale. Study on land suitability especially for pepper cultivation is still very few, therefore, this study can probably serve as an effort in increasing productivity of pepper cultivation.

\section{MATERIALS AND METHODS}

The study was conducted in Tirtomoyo District, Wonogiri Regency, Central Java, Indonesia. The study was conducted using an explorative descriptive survey method consisting of field observation and laboratory analysis. The soil samples taken from field were analysed in the laboratory in order to determine soil $\mathrm{pH}$ (electrometric method), soil texture (3 fraction method), Cation Exchange Capacity and Base Saturation ( $\mathrm{NH}_{4} \mathrm{OAc}$ extraction), Total-P and Total-K (25\% HCl extraction), organic carbon (Walkley and Black method) and Total-N (Kjeldahl method) following the procedures proposed by Eviati and Sulaeman (2012).

The analytical unit used in this study was the Land Map Unit (LMU) obtained from the secondary data of Land Type Map from the Indonesian Center for Agricultural Land Resources Research, which was processed using ArcGis 10.1 application. Sampling sites were selected using purposive sampling method in order to fit the research objectives. Other important considerations for the sampling points are the proportion and the presence of the required aspects and accessibility of the sampling points to be studied.

Land suitability evaluation was done by matching the land characteristics and the requirements of pepper growth. Land suitability classification refers to the Framework of Land Evaluation by FAO (1976), using three categories, namely orders, classes, and subclasses. Requirements of pepper growth refer to the criteria developed by Ritung et al. (2011) (Table 1). The results of the evaluation will show the limiting factors of land suitability for pepper growth.

\section{RESULTS AND DISCUSSION}

\section{Actual Land Suitability}

The survey on land suitability for pepper in Tirtomoyo District was divided into 4 LMU (Land Map Unit) obtained from secondary data of Land Type Map. The structure of land suitability classification according to Ritung et al. (2011) refers to FAO (Food and Agriculture Organization of the United Nations) Framework of Land Evaluation which divides land suitability into several levels. Land suitability based on Framework of Land Evaluation (FAO 1976) consists of the level of Order, Class, and Sub-Class. Based on the data obtained from the field and laboratory analysis, it was found that the actual land suitability class for each LMU is similar, namely S3 or marginally suitable. The data of land suitability is presented in Table 4 and the actual land suitability map is presented in Figure 1.

\section{The Limiting Factors}

The first limiting factor present in all LMU (LMU 1 to LMU 4) is water availability (wa) or the length of dry month. The number of dry month in the District of Tirtomoyo according to the data obtained from the Selogiri Agricultural Special Climatology Station is 4 months. The number of dry month is based on Schmidt-Fergusson's climate classification using the average of rainfall data over the past ten years, thus classifying the Tirtomoyo District into S3 class. Other subclasses for the same characteristic factors such as rainfall and humidity indicated good numbers and can be classified into S1 class. 
Table 1. Qualification and characteristics of land required for pepper growth (Ritung et al. 2011).

\begin{tabular}{|c|c|c|c|c|}
\hline Land Characteristics & S1 & S2 & S3 & $\mathrm{N}$ \\
\hline \multicolumn{5}{|l|}{ Temperature (tc) } \\
\hline \multirow[t]{2}{*}{ Average temperature $\left({ }^{\circ} \mathrm{C}\right)$} & $23-32$ & $20-23$ & - & $>34$ \\
\hline & & $32-34$ & & $<20$ \\
\hline \multicolumn{5}{|l|}{ Water availability (wa); } \\
\hline \multirow[t]{2}{*}{ Rain fall $\left(\mathrm{mm} \mathrm{yr}^{-1}\right)$} & $2000-2500$ & $2500-3000$ & $3000-4000$ & $<1500$ \\
\hline & & & $1500-2000$ & $>4000$ \\
\hline Humidity (\%) & $60-80$ & - & - & $<50$ \\
\hline Dry Month & $<2$ & $<3$ & $3-4$ & $>5$ \\
\hline \multicolumn{5}{|l|}{ Oxygen availability (oa); } \\
\hline Drainage & $\begin{array}{l}\text { well drained, } \\
\text { moderately well } \\
\text { drained }\end{array}$ & $\begin{array}{l}\text { somewhat poorly } \\
\text { drained }\end{array}$ & $\begin{array}{c}\text { poorly drained, } \\
\text { somewhat } \\
\text { excessively } \\
\text { drained }\end{array}$ & $\begin{array}{l}\text { very poorly } \\
\text { drained, } \\
\text { excessively } \\
\text { drained }\end{array}$ \\
\hline \multicolumn{5}{|l|}{$\begin{array}{l}\text { Rooting depth characteristic } \\
\text { (rc); }\end{array}$} \\
\hline Texture & $\begin{array}{l}\text { medium, quite } \\
\text { fine, fine }\end{array}$ & quite coarse & coarse, very fine & very coarse \\
\hline Coarse material (\%) & $<15$ & $15-35$ & $35-55$ & $>55$ \\
\hline Soil effective depth $(\mathrm{cm})$ & $>75$ & $50-75$ & $30-50$ & $<30$ \\
\hline \multicolumn{5}{|l|}{ Nutrient retention (nr) ; } \\
\hline $\operatorname{CEC}\left(\mathrm{me} 100 \mathrm{gr}^{-1}\right)$ & $>16$ & $5-16$ & $<5$ & \\
\hline Base saturation (\%) & $>50$ & $35-50$ & $<35$ & \\
\hline $\mathrm{pH} \mathrm{H} \mathrm{H}_{2} \mathrm{O}$ & $5.0-7.0$ & $4.0-5.0$ & $<4.0$ & \\
\hline Organic-C (\%) & $>0.4$ & $\leq 0.4$ & & \\
\hline \multicolumn{5}{|l|}{ Nutrient availability (na) } \\
\hline Total-N (\%) & $0.21-0.50$ & $0.10-0.20$ & $<0.10$ & \\
\hline $\mathrm{P}_{2} \mathrm{O}_{5}\left(\mathrm{mg} 100 \mathrm{~g}^{-1}\right)$ & $21-40$ & $15-20$ & $<15$ & \\
\hline $\mathrm{K}_{2} \mathrm{O}\left(\mathrm{cmol} \mathrm{kg}^{-1}\right)$ & $21-40$ & $10-20$ & $<10$ & \\
\hline \multicolumn{5}{|l|}{ Toxicity (xc) } \\
\hline Salinity $\left(\mathrm{dS} \mathrm{m}^{-1}\right)$ & $<5$ & $5-8$ & $8-10$ & $>10$ \\
\hline \multicolumn{5}{|l|}{ Solidity (xn) } \\
\hline Alkalinity /ESP (\%) & $<10$ & $10-15$ & $15-20$ & $>20$ \\
\hline \multicolumn{5}{|l|}{ Erosion Hazard (eh) ; } \\
\hline Slope (\%) & $<8$ & $8-15$ & $15-30$ & $>30$ \\
\hline Erosion hazard & very low & low - medium & high & very high \\
\hline \multicolumn{5}{|l|}{ Land preparation (lp) ; } \\
\hline Surface rocks $(\%)$ & $<5$ & $5-15$ & $15-40$ & $>40$ \\
\hline Rock outcrop (\%) & $<5$ & $5-15$ & $15-40$ & $>40$ \\
\hline
\end{tabular}

The next limiting factor present in all LMU is nutrient availability (na) or total-P content in soil. The total-P content in each LMU is very low. Eviati and Sulaeman (2012) indicated that the total P content in soil is categorized as very low if the content less than $15 \mathrm{mg} \mathrm{P}_{2} \mathrm{O}_{5} 100 \mathrm{~g}^{-1}$ soil in $25 \%$ $\mathrm{HCl}$ extraction. Another inhibiting parameter in nutrient availability (na) is the total-K content in soil. The total-K content in each LMU shows the same pattern as the total-P, except for LMU 1, which is classified into S2 class. Other LMUs are classified into $\mathrm{S} 3$ suitability class because the total-K is low.
Another limiting factor present in LMU 1 and LMU 2 is nutrient retention (nr) or base saturation. According to criteria proposed by Eviati and Sulaeman (2012), the soil base saturation in LMU 1 and LMU 2 are low. Base saturation in the soil is determined by the large number of base cations present in the soil solution and the exchange complex.

Another limiting factor, especially in LMU 3 and LMU 4 is rooting depth characteristic (rc). The inhibiting parameter in this factor is soil texture. The soils both in LMU 3 and LMU 4 have similar texture, 
Table 2. Drainage classification (Ritung et al. 2011).

\begin{tabular}{ll}
\hline \multicolumn{1}{c}{ Soil Morphology } & \multicolumn{1}{c}{ Drainage Class } \\
\hline Soil without redoxiomorphic features & Excessively drained \\
Soil without redoxiomorphic features & Somewhat excessively drained \\
Soil without redoxiomorphic features to a depth $\geq 100 \mathrm{~cm}$ & Well drained \\
Soil without redoxiomorphic features to a depth $\geq 50 \mathrm{~cm}$ & Moderately well drained \\
Soil without redoxiomorphic features to a depth $\geq 25 \mathrm{~cm}$ & Somewhat poorly drained \\
Soil with slight redoxiomorphic features in all layers & Poorly drained \\
Soil with redoxiomorphic features in all layers & Very poorly drained \\
\hline
\end{tabular}

Table 3. Soil texture classification (Ritung et al. 2011).

\begin{tabular}{ll}
\hline \multicolumn{1}{c}{ Texture } & \multicolumn{1}{c}{ Texture Class } \\
\hline Clay (2:1 clay mineral) & Very fine \\
Clay, silty clay, sandy clay & Fine \\
Clay loam, silty clay loam, sandy clay loam & Quite fine \\
Loam, silty loam, fine sandy loam & Medium \\
Sandy loam & Quite coarse \\
Loamy sand & Coarse \\
\hline
\end{tabular}

namely fine texture. This is because the LMUs are dominated by clay texture both in layer 1 and layer 2. Texture affects soil pore condition. The pores on the soil will control the hydrological processes in plants' rooting areas (Wahjuni et al. 2008). Soil with clay texture can cause soil compaction. Soil compaction can inhibit root exploration and reduce soil permeability (Martin and Rahmat 2017).
The last limiting factor found on the lands, especially in LMU 1 and LMU 4 was erosion hazard (eh). The inhibiting parameter in this factor is the slopes which range from $15 \%$ to $30 \%$. According to Central Bureau of Statistics of Wonogiri (2015), Tirtomoyo Region is one of the districts in Wonogiri that is dominated by hilly and rocky mountains. The flat area of Tirtomoyo District is located in the middle,

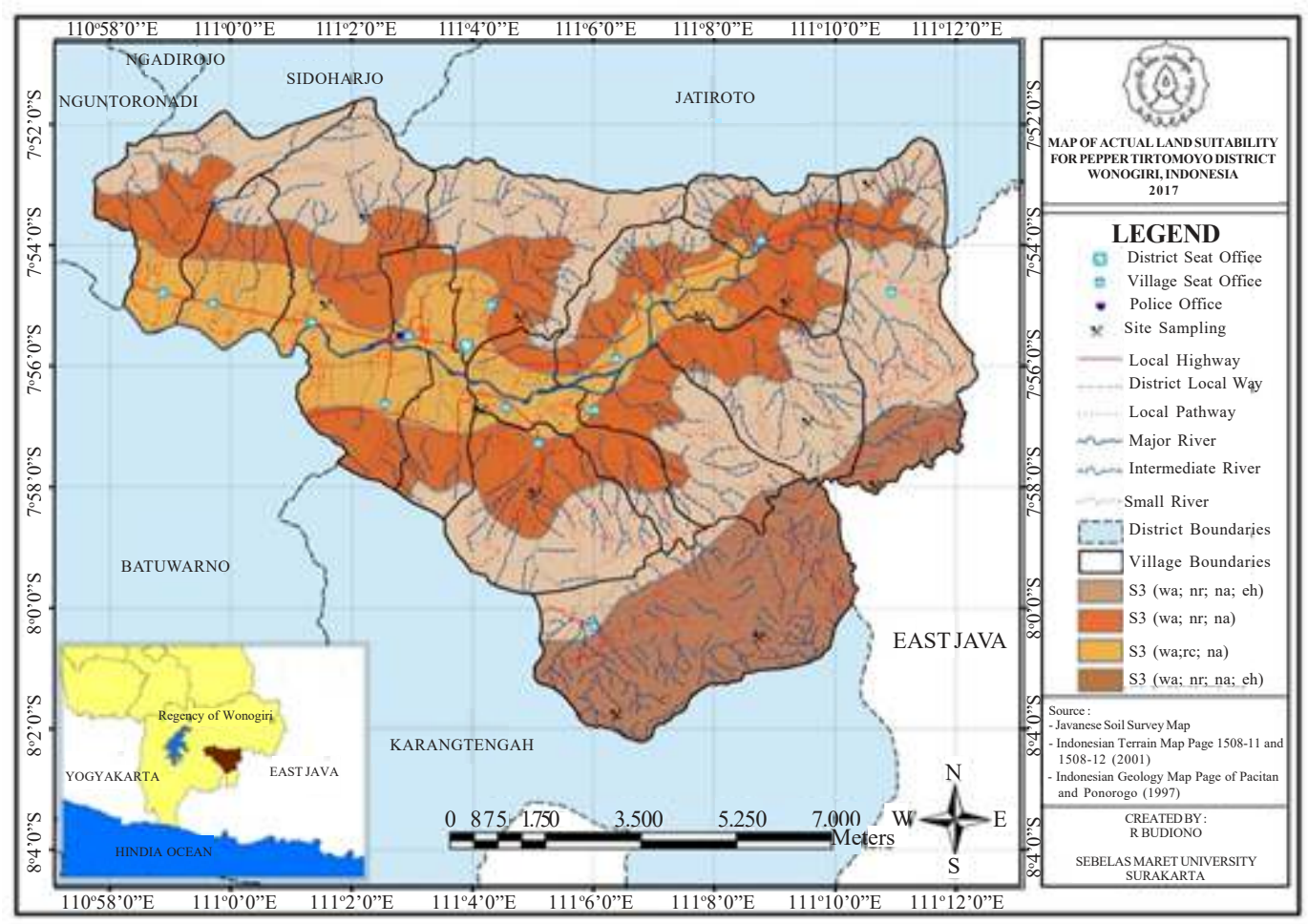

Figure 1. Map of actual land suitability for pepper of the study area. 
Table 4. Actual land suitability for pepper.

\begin{tabular}{|c|c|c|c|c|}
\hline Land Characteristics & LMU 1 & LMU 2 & LMU 3 & LMU4 \\
\hline \multicolumn{5}{|l|}{ Temperature (tc) } \\
\hline Average temperature $\left({ }^{\circ} \mathrm{C}\right)$ & 23 & 25 & 25 & 21 \\
\hline \multicolumn{5}{|l|}{ Water availability (wa); } \\
\hline Rainfall $\left(\mathrm{mm} \mathrm{yr}^{-1}\right)$ & 2120 & 2120 & 2120 & 2120 \\
\hline Humidity (\%) & 96 & 96 & 96 & 96 \\
\hline Dry Month & 4 & 4 & 4 & 4 \\
\hline \multicolumn{5}{|l|}{ Oxygen availability (oa) ; } \\
\hline Drainage & $\begin{array}{l}\text { Moderately well } \\
\text { drained }\end{array}$ & $\begin{array}{l}\text { Moderately } \\
\text { well drained }\end{array}$ & $\begin{array}{l}\text { Moderately } \\
\text { well drained }\end{array}$ & $\begin{array}{l}\text { Moderately well } \\
\text { drained }\end{array}$ \\
\hline \multicolumn{5}{|l|}{$\begin{array}{l}\text { Rooting depth characteristic } \\
\text { (rc); }\end{array}$} \\
\hline Texture & medium & medium & very fine & very fine \\
\hline Coarse material (\%) & $<15$ & $<15$ & $<15$ & $<15$ \\
\hline Soil effective depth $(\mathrm{cm})$ & $>150$ & $>150$ & $>150$ & $>150$ \\
\hline \multicolumn{5}{|l|}{ Nutrient retention $(\mathrm{nr})$; } \\
\hline $\mathrm{CEC}\left(\mathrm{me} 100 \mathrm{~g}^{-1}\right)$ & 21 & 18 & 18 & 17 \\
\hline Base saturation (\%) & 33 & 32 & 35 & 37 \\
\hline $\mathrm{pH} \mathrm{H} \mathrm{H}_{2} \mathrm{O}$ & 5.7 & 6.1 & 6.2 & 5.8 \\
\hline Organic-C (\%) & 0.9 & 1.3 & 0.9 & 0.9 \\
\hline \multicolumn{5}{|l|}{ Nutrient availability (na) } \\
\hline Total N (\%) & 0.24 & 0.33 & 0.18 & 0.21 \\
\hline $\mathrm{P}_{2} \mathrm{O}_{5}\left(\mathrm{mg} 100 \mathrm{~g}^{-1}\right)$ & 6.17 & 10.29 & 7.19 & 6.11 \\
\hline $\mathrm{K}_{2} \mathrm{O}\left(\mathrm{cmol} \mathrm{kg}^{-1}\right)$ & 20.82 & 19.15 & 8.71 & 11.39 \\
\hline \multicolumn{5}{|l|}{ Toxicity (xc) } \\
\hline Salinity $\left(\mathrm{dS} \mathrm{m}^{-1}\right)$ & 0 & 0 & 0 & 0 \\
\hline \multicolumn{5}{|l|}{ Solidity (xn) } \\
\hline Alkalinity per ESP (\%) & 0 & 0 & 0 & 0 \\
\hline \multicolumn{5}{|l|}{ Erosion Hazard (eh) ; } \\
\hline Slope $(\%)$ & $15-30$ & $8-15$ & $<8$ & $15-30$ \\
\hline Erosion hazard & medium & medium & low & low \\
\hline \multicolumn{5}{|l|}{ Land preparation (lp); } \\
\hline Surface rocks $(\%)$ & $<5$ & $<5$ & $<5$ & $<5$ \\
\hline Rock outcrop (\%) & $<5$ & $<5$ & $<5$ & $<5$ \\
\hline Actual Land Suitability & S3 (wa;nr; na;eh) & S3 (wa;nr;na) & S3 (wa;rc;na) & S3 (wa;rc;na;eh) \\
\hline
\end{tabular}

around the stream of Wiroko river. The slopes in this region start to increase from the central area of the district to the north and south.

\section{Recommendation to Overcome the Limiting Factors}

Based on the data obtained in the field survey and soil analysis in the laboratory, the main limiting factors for the pepper growth requirements in Tirtomoyo district are water availability (wa), nutrient retention (nr), nutrient availability (na), rooting depth characteristic (rc) and erosion hazard (eh). Counter measures for the limiting factors can be potentially used to determine the class of land suitability. Recommendations of measures that can be performed are presented in Table 5 to Table 8 , and potential land suitability map is presented in Figure 2.

One of the measures that can be applied to overcome the inhibiting factors is by applying irrigation when the drought occurs. The type of irrigation technique can be adjusted to the scale of the improvement measures on the land. According to the study conducted by Suhaendah et al. (2016), the pepper farmers in the regions of Konawe and East Kolaka, Southeast Sulawesi, Indonesia use bamboo infusion irrigation model (drip irrigation technique) that can adapt to the water condition at the land with an affordable cost. The application of this irrigation technique is considered to be quite effective in tackling the process of pepper cultivation during dry season. 
Table 5. Improvement measures that can be applied in LMU 1.

\begin{tabular}{|c|c|c|}
\hline Inhibiting Factors & Improvement measures & Potential Land Suitability \\
\hline Dry month & Irrigation & \\
\hline Base saturation & Organic material addition & \\
\hline $\mathrm{P}_{2} \mathrm{O}_{5}$ content & $\begin{array}{l}\text { Fertilization, functional bacterial } \\
\text { inoculation, amelioration }\end{array}$ & \\
\hline $\mathrm{K}_{2} \mathrm{O}$ content & $\begin{array}{l}\text { Fertilization, functional bacterial } \\
\text { inoculation, amelioration }\end{array}$ & S2 (nr;na;eh) \\
\hline Slope & $\begin{array}{l}\text { Cover crop planting and agroforestry } \\
\text { modeling }\end{array}$ & \\
\hline Erosion hazard & $\begin{array}{l}\text { Cover crop planting and agroforestry } \\
\text { modeling }\end{array}$ & \\
\hline
\end{tabular}

Note: $\mathrm{nr}=$ nutrient retention (base saturation); $\mathrm{na}=$ nutrient availability $\left(\mathrm{P}_{2} \mathrm{O}_{5}\right.$ content); eh = erosion hazard (slope).

Table 6. Improvement measures that can be applied in LMU 2.

\begin{tabular}{|c|c|c|}
\hline Inhibiting Factors & Improvement measures & Potential Land Suitability \\
\hline Dry month & Irrigation & \\
\hline Base saturation & Organic material addition & \\
\hline $\mathrm{P}_{2} \mathrm{O}_{5}$ content & $\begin{array}{l}\text { Fertilization, functional bacterial } \\
\text { inoculation, amelioration }\end{array}$ & \\
\hline $\mathrm{K}_{2} \mathrm{O}$ content & $\begin{array}{l}\text { Fertilization, functional bacterial } \\
\text { inoculation, amelioration }\end{array}$ & S2 (nr;na) \\
\hline Slope & $\begin{array}{l}\text { Cover crop planting and agroforestry } \\
\text { modeling }\end{array}$ & \\
\hline Erosion hazard & $\begin{array}{l}\text { Cover crop planting and agroforestry } \\
\text { modeling }\end{array}$ & \\
\hline
\end{tabular}

Note: $\mathrm{nr}=$ nutrient retention (base saturation); $\mathrm{na}=$ nutrient availability $\left(\mathrm{P}_{2} \mathrm{O}_{5}\right.$ content and $\mathrm{K}_{2} \mathrm{O}$ content).

Table 7. Improvement measures that can be applied in LMU 3.

\begin{tabular}{lll}
\hline \multicolumn{1}{c}{ Inhibiting Factors } & \multicolumn{1}{c}{ Improvement measures } & Potential Land Suitability \\
\hline Dry month & Irrigation & \\
Base saturation & Organic material addition & \\
$\mathrm{N}$ total & Fertilization, functional bacterial & \\
& inoculation, amelioration & $\mathrm{S} 2(\mathrm{rc})$ \\
$\mathrm{P}_{2} \mathrm{O}_{5}$ content & Fertilization, functional bacterial & \\
& inoculation, amelioration \\
$\mathrm{K}_{2} \mathrm{O}$ content & Fertilization, functional bacterial \\
& inoculation, amelioration \\
\hline
\end{tabular}

Clay texture can potentially cause soil compaction. Soil compaction can reduce soil porosity and inhibit permeability. Soil texture is the soil characteristic that is difficult to change. Management measure that can reduce the negative effects of clay texture is the application of organic fertilizers. Organic fertilizers can improve soil physical properties such as increasing soil porosity and permeability (Soelaeman and Haryati 2012; Prasetyo et al. 2014; Sanjaya et al. 2016).
Fertilization can increase nutrient availability and will improve the land suitability class. According to the study conducted by Zörb et al. (2014), fertilization is the most visible way to increase the availability of $\mathrm{K}$ in soil, such as $\mathrm{KCl}$ that is commonly sold in the market and other $\mathrm{K}$ fertilizers such as $\mathrm{K}_{2} \mathrm{SO}_{4}$ and $\mathrm{KNO}_{3}$. The use of natural mineral fertilizer is also one of the efforts to improve the $\mathrm{K}$ availability in soil. The outcome of fertilization will probably be more effective by applying combinations 
Table 8. Improvement measures that can be conducted in LMU 4.

\begin{tabular}{|c|c|c|}
\hline Inhibiting Factors & Improvement measures & Potential Land Suitability \\
\hline Dry month & Irrigation & \multirow{7}{*}{$\mathrm{S} 2(\mathrm{rc})$} \\
\hline Base saturation & Organic material addition & \\
\hline Total-N & $\begin{array}{l}\text { Fertilization, functional bacterial } \\
\text { inoculation, amelioration }\end{array}$ & \\
\hline $\mathrm{P}_{2} \mathrm{O}_{5}$ content & $\begin{array}{l}\text { Fertilization, functional bacterial } \\
\text { inoculation, amelioration }\end{array}$ & \\
\hline $\mathrm{K}_{2} \mathrm{O}$ content & $\begin{array}{l}\text { Fertilization, functional bacterial } \\
\text { inoculation, amelioration }\end{array}$ & \\
\hline Slope & $\begin{array}{l}\text { Cover crop planting and agroforestry } \\
\text { modeling }\end{array}$ & \\
\hline Erosion hazard & $\begin{array}{l}\text { Cover crop planting and agroforestry } \\
\text { modeling }\end{array}$ & \\
\hline
\end{tabular}

Note: $\mathrm{rc}=$ rooting depth characteristic (soil texture).

of fertilizers and other treatments such as the application of Plant Growth Regulation (PGR), organic materials such as farmyard manure (FYM) and functional microorganisms. In some cases, the effects of the treatments will improve the amount of nutrients present in the soil.

In addition to fertilization, another measure that can be done to overcome the limiting factor is by applying ameliorant (repairing agent) such as biochar. This is in line with the study conducted by Liu et al. (2017) that shows that the application of biochar made from rice husks increased the availability of $\mathrm{P}$ in acidic soils.
According to Ritung et al. (2011), slopes are related to plant production and environmental sustainability. Slopes are associated with soil erosion. The study conducted by Lenka et al. (2017) indicated that to reduce the negative impact of slopes that are prone to erosion, sprouting cultivation on different contours can be applied by letting grass grow on the slope areas. Further study about cover plants on slope areas was conducted by Biddoccu et al. (2016) in a mountainous area in Italy which suggested that grass covering on slope areas in combination with minimum soil tillage is highly

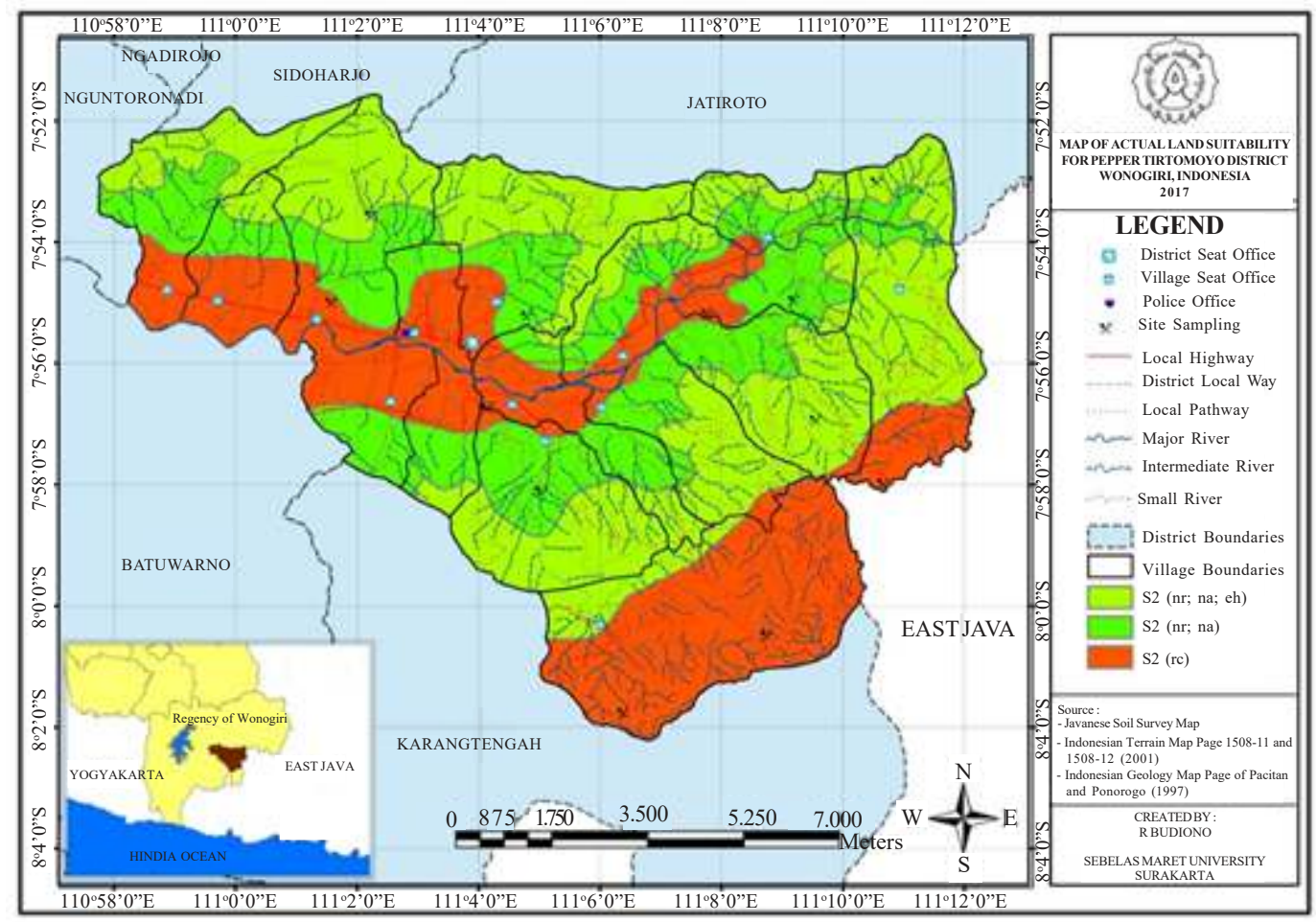

Figure 2. Map of potential land suitability for pepper of the study area. 
effective in reducing slope hazards that can cause soil loss due to erosion.

Agroforestry systems are able to improve land productivity and provide ecosystem services by reducing potential erosion (Hillbrand et al. 2017). The presence of trees can increase soil infiltration capacity, so that run-off decreases, and the potential erosion decreases (Siriri et al. 2013). Applications of organic materials from litter can increase soil porosity and soil permeability (Soelaeman and Haryati 2012). The existence of plant roots are capable of breaking up soil compaction, thus increasing the soil infiltration capacity (Wang et al. 2015).

\section{CONCLUSIONS}

The actual land suitability for the pepper (Piper nigrum L.) in all LMU of Tirtomoyo district is categorized as $\mathrm{S} 3$ class or marginally suitable class with similar limiting factors, namely water availability (wa) and nutrient availability (na). There were two additional factors of nutrient retention (nr) and erosion hazard (eh) in LMU 1; an additional factor of nutrient retention (nr) in LMU 2; an additional factor of rooting depth characteristic (rc) in LMU 3 ; and additional factors of rooting depth characteristic (rc) and erosion hazard (eh) in LMU 4. The measure that can be applied to overcome the limiting factor of water availability (wa) is irrigation. The measures that can be applied to overcome the limiting factor of nutrient retention (nr) and nutrient availability (na) are fertilization and application of functional bacterial inoculants and soil ameliorant. The measures that can be applied to overcome the limiting factor of erosion hazard (eh) is planting cover crops and applying agroforestry system.

The potential land suitability for pepper (Piper nigrum L.) of LMU 1 and LMU 2 is S2 with the same limiting factors, namely nutrient retention (nr) and nutrient availability (na); there is an additional factor of erosion hazard (eh) in LMU 1. The potential land suitability of LMU 3 and LMU 4 is S3 with the same limiting factor of rooting depth characteristic (rc).

\section{ACKNOWLEDGEMENTS}

The study was supported by Universitas Sebelas Maret Surakarta under the research grant of PNBP UNS 2016-2019.

\section{REFERENCES}

Badan Pusat Statistika Kabupaten (Central Beurrau of Statistics) Wonogiri. 2015. Statistik Daerah Kecamatan Tirtomoyo Tahun 2015.

Biddoccu M, S Ferraris, F Opsi and E Cavallo. 2016. Longterm monitoring of soil management effects on runoff and soil erosion in sloping vineyards in Alto Monferrato (North-West Italy). Soil Till Res 155: 176-189.

Eviati and Sulaeman. 2012. Analisis Kimia Tanah, Tanaman, Air dan Pupuk. Badan Penelitian dan Pengembangan Pertanian. Bogor. (in Indonesian).

FAO. 1976. A Framework for Land Evaluation. Soil Resources Management and Conservation Service Land and Water Development Division.FAO Soil Bulletin No.32.FAO-UNO, Rome.

Hillbrand A, S Borelli, M Conigliaro and E Olivier. 2017. Agroforestry for landscape restoration: exploring the potential of agroforestry to enhance the sustainability and resilience of degraded landscapes. FAO. Rome.

International Pepper Community. 2005. Pepper (Piper nigrum ) Production Guide for Asia and the Pacific. http://www.ipcnet.org/market-review. access date $29^{\text {th }}$ of March 2016.

Lenka NK, KK Satapathy, R Lal, RK Singh, NAK Singh, PK Agrawal, P Chudury and A Rathore. 2017. Weed strip management for minimizing soil erosion and enhancing productivity in the sloping lands of north-eastern India. Soil Till Res 170: 104-113.

Liu S, J Meng, L Jiang, X Yang, Y Lan, X Cheng and W Chen. 2017. Rice husk biochar impacts soil phosphorous availability, phosphatase activities and bacterial community characteristics in three different soil types. Appl Soil Ecol 116: 12-22.

Manohara D and D Wahyuno. 2013. Pedoman Budidaya Merica. Balai Penelitian Obat dan Rempah. Bogor

Martin DAN and A Rahmat. 2017. Relationship of Soil Physicochemical Properties and Existence of Phytophthora sp. in Pineapple Plantations. Ind $J$ Sci Tech 2: 81-86.

Mujiyo M, H Widijanto, A Herawati, F Rochman and R Rafirman. Potensi Lahan untuk Budidaya Pisang Di Kecamatan Jenawi Karanganyar. Caraka Tani: $J$ Sustain Agr 32: 142-148.

Prasetyo A, WH Utomo and E Listyorini. 2017. Hubungan sifat fisik tanah, perakaran dan hasil ubi kayu tahun kedua pada Alfisol Jatikerto akibat pemberian pupuk organik dan anorganik (NPK). J Tanah dan Sumberdaya Lahan 1:27-37. (in Indonesian).

Ravindran PN. 2012. Black Papper.Indian Institute of Spices Research, India

Ritung S, K Nugroho, A Mulyani dan E Suryani. 2011. Petunjuk Teknis Evaluasi Lahan Untuk Komoditas Pertanian (Edisi Revisi). Balai Besar Penelitian dan Pengembangan Sumberdaya Lahan Pertanian, Badan Penelitian dan Pengembangan Pertanian, Bogor. (in Indonesian). 
Sanjaya JH, Afandi, NA Afrianti and H Novpriansyah. 2016. Pengaruh Effluent Sapi Terhadap Beberapa Sifat Fisik Dan Kimia Tanah Pada Lahan Ultisol Di PT Great Giant Pineapple Lampung Tengah. J Agrotek Tropika 4: 105-110.

Siriri D, J Wilson, R Coe, MM Tenywa, MA Bekunda, CK Ong and CR Black. 2013. Trees improve water storage and reduce soil evaporation in agroforestry systems on bench terraces in SW Uganda. Agrofor Syst 87: 45-58.

Soelaeman Y and U Haryati. 2012. Soil Physical Properties and Production of Upland Ultisol Soil. Agrivita. $J$ Agr Sci 34: 136-143.

Suhaendah E, E Fauziyah and GE Manurung. 2016. Adaptasi Petani Lada Terhadap Perubahan Iklim di Desa Lawonua dan Desa Simbune, Sulawesi Tenggara. Prosiding Seminal Nasional Geografi UMS 2016. (in Indonesian).
Wahjuni ED, O Haridjaja, H Soedodo and Sudarsono. 2008. Water Movement in the Soil with Different Pore Characteristics and Its Effect to Crop Water Availability. J Tanah dan Iklim 28: 15-26.

Wang L, C Zhong, P Gao, W Xi and S Zhang. 2015. Soil infiltration characteristics in agroforestry systems and their relationships with the temporal distribution of rainfall on the loess Plateau in China. PloS one, 10(4), e0124767. doi: https://doi.org/ 10.1371/journal.pone. 0124767

Zörb C, M Senbayram and E Peiter. 2014. Potassium in agriculture-status and perspectives. J plant Phy 171: 656-669. 
